\title{
PERKEMBANGAN KOGNITIF ANAK USIA DINI DALAM PERSPEKTIF VYGOTSKY DAN IMPLIKASINYA DALAM PEMBELAJARAN
}

\author{
Angga Saputra, ${ }^{1}$ Lalu Suryandi $i^{2}$ \\ Institut Agama Islam Qamarul Huda \\ pgraku@gmail.com
}

\section{ABSTRAK}

Adapun yang menjadi tujuan dalam penelitian ini adalah ingin mengaji konsep pemikiran vygotsky mengenai perkembangan kognitif anak usia dini serta bagaimana implikasinya dalam pembelajaran. Jenis dalam penelitian ini menggunakan kajian pustaka (library research) dengan teknik pengumpulan data berupa dokumen. Setelah data-data itu diperoleh, peneliti mengolah data-data tersebut dengan cara dibaca dan dianalisis kemudian disimpulkan. Hasil menunjukan bahwa Pertama, kemampuan kognitif dimediasi dengan kata, dan diskursus yang berfungsi sebagai alat psikologis untuk membantu serta mentransformasi aktivitas mental. Kedua, kemampuan kognitif berasal dari relasi social dan dipengaruh oleh latar belakang sosiol kultural.

Kata Kunci: Perkembangan Kognitif, Anak Usia Dini dan Implikasi

\section{PENDAHULUAN}

Anak sejak lahir sampai usia 6 tahun merupakan pondasi awal bagi pertumbuhan dan perkembangan anak selanjutnya. Pada usia ini pertumbuhan fisik dan perkembangan mental anak terjadi sangat pesat. Sekalipun tuhan telah memberikan potensi kepada anak, lingkungan memberikan sikap, kepribadian dan pengembangan pembelajaran kepada anak. Setiap anak yang lahir bersifat unik dengan potensi yang berbeda-beda, memiliki kelebihan, bakat dan minat sendiri-sendiri yang dikembangan melalui proses pendidikan ${ }^{1}$

\footnotetext{
${ }^{1}$ Wulandari Retnaningrum, Peningkatan Perkembangan Kognitif Anak Usia Melalui Media Bermain Memancing. Jurnal Pendidikan dan Pemberdayaan Masyarakat. Vol. 3 No. 2, November 2016.
}

Jurnal Pelang̉i Jurnal pemikiran dan penelitian pendidikan Islam anak Usia Dini 
Menurut Benjamin S. Bloom dalam bukunya, Stability and Change in Human Characteristics, menjelaskan bahwa pada usia empat tahun, separuh potensi kecerdasan telah terbentuk sehingga apabila pada usia 0-4 tahun seorang anak tidak mendapatkan rangsangan otak yang tepat seperti media atau metode, kinerja otaknya tidak dapat berkembang secara maksimal dan 80\% kecerdasan anak tercapai pada usia delapan tahun. ${ }^{2}$

Pada masa anak-anak atau pun usia pada saat sekolah mengalami perkembangan kognitifyang terus berkembang, dari mulai masa bayi sampai anak remaja. Salah satu kemampuan dasar anak yang perlu dikembangkan serta akan sangat berpengaruh terhadap pertumbuhan dan perkembangan pada aspek lain adalah perkembangan kognitif. ${ }^{3}$ Ada dua teori yang menerangkan perkembangan kognitif yang dialami pada anak, dua tokoh tersebut itu adalah pieget dan Vygotsky namun pada kali ini peneliti lebih mengfokuskan pada pemikiran Vygotsky dimana beliau merupakan salah satu pelopor ilmuan yang sangat terkenal dengan teori Zone of Proximal Development (ZPD) dan peranan konteks sosial dalam perkembangan anak usia dini. Perkembangan kognitif merupakan perkembangan pikiran. Pikiran anak adalah bagian dari otaknya yang bertanggung jawab terhadap bahasa, pembentukan mental, pemahaman, penyelesaian masalah, pandangan, penilaian, pemahaman sebab akibat, serta ingatan.

Teori Vygotsky mengatakan bahwa pembelajaran mendahului perkembangan. Pembelajaran melibatkan perolehan tanda-tanda melalui pengajaran dan informasi dari orang lain.Vygostsky percaya bahasa adalah alat yang paling penting. Vygostsky berpendapat bahwa pada masa kanakana awal (early childhood) bahasa mulai digunakan sebagai alat yang membantu anak untuk merancang aktivitas dan memecahkan broblem. ${ }^{4}$

Maka dari berbagai perspektif di atas peneliti merasa perlu dilakukan sebuah riset yang mendalam bagaimana konsep berpikir Vygotsky dalam perkembangan kognitif anak usia dini dan bagaimana implikasinya dalam pembelajaran.

(207-218), hal.23.

${ }^{2}$ Angga Saputra, Kompetensi Pedagogik Guru PAUD dalam Meningkatkan Nilai-Nilai Sosial, Moral dan Keagamaan Melalui Metode Bercerita, KINDERGARTEN; Journal of Islamic Early Childhood Education. Vol. 3, No. 1, April 2020. hal. 85-91

${ }^{3}$ Mena \& Eyer, Infants, Toddlers, And Caregivers, (New York: McGraw-1l, 2009), hal.175

${ }^{4}$ John W Santrok, Psikologi Pendidikan, (Jakarta: Kencana Media Group, 2007), hal.60 


\section{METODE PENELITIAN}

Penelitian ini menggunakan kajian pustaka (library research), yaitu serangkaian kegiatan yang berkenaan dengan metode pengumpulan data pustaka. Menurut Abdul Rahman Sholeh, penelitian kepustakaan (library research) ialah penelitian yangmengunakan cara untuk mendapatkan data informasi dengan menempatkan fasilitas yang ada di perpus, seperti buku, majalah, dokumen, catatan kisah-kisah sejarah. ${ }^{5}$

Peneliti menghimpun data melalui teknik pengumpulan data berupa dokumen. Setelah data-data itu diperoleh, peneliti mengolah data-data tersebut dengan cara dibaca dan dianalisis kemudian disimpulkan. ${ }^{6}$

\section{PEMBAHASAN}

\section{Konsep Sosiokultural}

Teori Vygotsky menawarkan suatu potret perkembangan manusia sebagai sesuatu yang tidak terpisahkan dari kegiatan-kegiatan sosial dan budaya. Vygotsky menekankan bagaimana proses-proses perkembangan mental seperti ingatan, perhatian, dan penalaran melibatkan pembelajaran menggunakan temuan-temuan masyarakat seperti bahasa, sistem matematika, dan alat-alat ingatan. Ia juga menekankan bagaimana anak-anak dibantu berkembang dengan bimbingan dari orang-orang yang sudah terampil di dalam bidang-bidang tersebut. Penekanan Vygotsky pada peran kebudayaan dan masyarakat di dalam perkembangan kognitif berbeda dengan gambaran Piaget tentang anak sebagai ilmuwan kecil yang kesepian. ${ }^{7}$

Piaget memandang anak-anak sebagai pembelajaran lewat penemuan individual, sedangkan Vygotsky lebih banyak menekankan peranan orang dewasa dan anak-anak lain dalam memudahkan perkembangan si anak. Menurut Vygotsky, anak-anak lahir dengan fungsi mental yang relatif dasar seperti kemampuan untuk memahami

${ }^{5}$ Abdul Rahman Sholeh, Pendidikan Agama dan Pengembangn Untuk Bangsa, ( Jakarta: PT. Raja Grafindo Persada, 2005). 63

${ }^{6}$ Angga Saputra \& Maemonah, Pendidikan Untuk Anak Usia Dini Usia 0-2 Tahun dalam Perspektif Ibnu Qoyyim Al-Jaujiyyah, Vol. 4 No. 2 Desember 2019. 147.144.

${ }^{7}$ Robert E Salvin, Psikologi Pendidikan Teori \& Praktik, (Jakarta: Indeks Person, 2008), 59.

Jurnal Pelangi Jurnal pemikiran dan penelitian pendidikan Islam anak Usia Dini 
dunia luar dan memusatkan perhatian. Namun, anak-anak tidak banyak memiliki fungsi mental yang lebih tinggi seperti ingatan, berfikir dan menyelesaikan masalah. Fungsi-fungsi mental yang lebih tinggi ini dianggap sebagai "alat kebudayaan" tempat individu hidup dan alatalat itu berasal dari budaya. Alat-alat itu diwariskan pada anak-anak oleh anggota-anggota kebudayaan yang lebih tua selama pengalaman pembelajaran yang dipandu. Pengalaman dengan orang lain secara berangsur menjadi semakin mendalam dan membentuk gambaran batin anak tentang dunia. Karena itulah berpikir setiap anak dengan cara yang sama dengan anggota lain dalam kebudayaannya.

Vygotsky menekankan baik level konteks sosial yang bersifat institusional maupun level konteks sosial yang bersifat interpersonal. Pada level institusional, sejarah kebudayaan menyediakan organisasi dan alatalat yang berguna bagi aktivitas kognitif melalui institusi seperti sekolah, penemuan seperti komputer, dan melek huruf. Interaksi institusional memberi kepada anak suatu norma-norma perilaku dan sosial yang luas untuk membimbing hidupnya. Level interpersonal memiliki suatu pengaruh yang lebih langsung pada keberfungsian mental anak.

Menurut Vygotsky, keterampilan-keterampilan dalam keberfungsian mental berkembang melalui interaksi sosial langsung. Informasi tentang alat-alat, keterampilan-keterampilan dan hubungan-hubungan interpersonal kognitif dipancarkan melalui interaksi langsung dengan manusia. Melalui pengorganisasian pengalaman-pengalaman interaksi sosial yang berada di dalam suatu latar belakang kebudayaan ini, perkembangan mental anak-anak menjadi matang.

\section{Zone Perkembangan Proksima}

Zona perkembangan proksimal adalah istilah Vygotsky untuk rangkaian tugas yang terlalu sulit dikuasai anak seorang diri tetapi dapat dipelajari dengan bantuan dan bimbingan orang dewasa atau anakanak terlatih. Batas bawah dari ZPD dinamakan aktual development yaitu tingkat keahlian yang dimiliki anak yang bekerja secara mandiri. Batas atas dinamakan potensial development yaitu tingkat tanggung jawab tambahan yang dapat diterima oleh anak dengan bantuan seorang instruktur. ${ }^{8}$

${ }^{8}$ http://kompasiana.com/post/2011/01/01/teori-piaget-dan-vygotsky/ diakses 4 Maret 
Dengan demikian, menurut teori Vygotsky, Zona Perkembangan Proksimal merupakan jarak antara actual development dan potential development yakni daerah tingkat perkembangan sedikit di atas daerah perkembangan seseorang saat ini. ${ }^{9}$ Vygotsky percaya pembelajaran terjadi ketika anak-anak bekerja dalam zona perkembangan proksimal mereka. Tugas-tugas dalam ZPT tersebut adalah sesuatu yang belum dapat dikerjakan seorang anak sendirian, tetapi masih membutuhkan bantuan teman atau orang dewasa yang lebih kompeten. Tingkat perkembangan yang dimaksud terdiri atas empat tahap yaitu:

Pertama, more dependence to others stage, yakni tahapan di mana kinerja anak mendapat banyak bantuan dari pihak lain seperti temanteman sebayanya, orang tua, guru, masyarakat, ahli, dan lain-lain. Dari sinilah muncul model pembelajaran kooperatif atau kolaboratif dalam mengembangkan kognisi anak secara konstruktif.

Kedua, less dependence external assistence stage, di mana kinerja anak tidak lagi terlalu banyak mengharapkan bantuan dari pihak lain, tetapi lebih kepada selfassistance, lebih banyak anak membantu dirinya sendiri.

Ketiga, Internalization and automatization stage, di mana kinerja anak sudah lebih terinternalisasi secara otomatis. Kasadaran akan pentingnya pengembangan diri dapat muncul dengan sendirinya tanpa paksaan dan arahan yang lebih besar dari pihak lain. Walaupun demikian, anak pada tahap ini belum mencapai kematangan yang sesungguhnya dan masih mencari identitas diri dalam upaya mencapai kapasitas diri yang matang.

Keempat, De-automatization stage, di mana kinerja anak mampu mengeluarkan perasaan dari kalbu, jiwa, dan emosinya yang dilakukan secara berulang-ulang, bolak-balik, recursion. Pada tahap ini, keluarlah apa yang disebut dengan de automatisation sebagai puncak dari kinerja sesungguhnya. ${ }^{10}$

Dengan demikian dalam proses untuk mencapai pemahaman pada mulanya anak diberikan bantuan/bimbingan untuk mencapai perkembangan yang optimal, setelah itu secara bertahap bantuan itu

2017.

${ }^{9}$ Trianto, Model-Model Pembelajaran Inovatif, (Jakarta: Prestasi Pustaka, 2007), hal. 39.

${ }^{10}$ http:/ / bk2009.files.wordpress.com/2011/01/teori-perkembangan-kognitif-vygotsky.doc diakses 4 Maret 2017.

Jurnal Pelang̉i Jurnal pemikiran dan penelitian pendidikan Islam anak Usia Dini 
dikurangi sampai akhirnya tidak diberikan sama sekali, sehingga anak secara independen dapat memahami apa yang mereka pelajari. oleh karena itu, Vigotsky mengajukan sebuah teori yang dikenal dengan istilah Zone of Proximal Development (ZPD) yang merupakan dimensi sosio-kultural yang penting sebagai dimensi psikologis. Zone of Proximal Development (ZPD) adalah istilah Vigotsky untuk merangkai tugas yang terlalu sulit dikuasai anak secara sendirian tetapi dapat dipelajari dengan bantuan dari orang dewasa atau anak yang lebih mampu. Penekanan Vigotsky pada ZPD menegaskan keyakinannya akan arti penting dari pengaruh sosial terutama pengaruh intruksi atau pengajaran terhadap perkembangan anak. ${ }^{11}$

Kata Zona digunakan Vygotsky sebagai perkembangan anakanak bukan sebagai titik-titik dalam sebuah skala tetapi rangkaian kesatuan keterampilan dan kemampuan pada tingkat kemampuan yang berbeda-beda. Ia menegaskan zona itu terbatas pada keterampilan dan kemampuan yang akan berkembang dalam waktu dekat. ${ }^{12}$

Menurut Wrets, ZPD merupakan kegiatan internalisasi kegiatan interpersonal seperti bercakap-cakap atau kegiatan bersama menjadi kegiatan mental yang dilakukan oleh seorang individu. ${ }^{13}$

\section{Konsep Scaffolding}

Scaffolding adalah memberikan dukungan dan bantuan kepada seorang anak yang sedang pada awal belajar, kemudian sedikit demi sedikit mengurangi dukungan atau bantuan tesebut setelah anak mampu memecahkan problem dari tugas yang dihadapinya. Scaffolding merupakan suatu istilah yang ditemukan oleh seorang ahli psikologi perkembangan-kognitif masa kini, Jerome Bruner, yakni suatu proses yang digunakan orang dewasa untuk menuntun anak-anak melalui zona perkembangan proksimalnya. ${ }^{14}$

Dialog adalah alat yang penting dalam ZPD. Vygotsky memandang anak-anak kaya konsep tetapi tidak sistematis, acak, dan spontan. Dalam

\footnotetext{
${ }^{11}$ John W Santrok, hal.60

${ }^{12}$ L. S. Vygotsky, Mind In Society The Development Of Hinher Psychological, (Amerika, Processes, 1979), hal.99

${ }^{13}$ Penney Upton, Psikologi Perkembangan, (Jakarta: Erlangga, 2012), 45.

${ }^{14} \mathrm{http} / /$ edukasi.kompasiana.com/2010/12/28/teori-kognitif-menurut-piaget-dan-vigotsky/ di akses 4 Maret 2017
} 
dialog, konsep-konsep tersebut dapat dipertemukan dengan bimbingan yang sistematis, logis, dan rasional.

\section{Bahasa dan Pemikiran}

Menurut Vygotsky, bahasa berkembang dari interaksi sosial dengan orang lain. Vygotsky berpendapat bahwa anak menggunakan pembicaraan bukan saja untuk komunikasi sosial, tetapi juga untuk membantu mereka menyelesaikan tugas. Lebih jauh Vygotsky yakin bahwa anak pada usia dini menggunakan bahasa untuk merencanakan, membimbing, dan memonitor perilaku mereka. Pada tahap pra operasional, ketika anak belajar menggunakan bahasa untuk menyelesaikan masalah, mereka berbicara lantang sembari menyelesaikan masalah. Sebaliknya, begitu menginjak tahap operasional konkret, percakapan batiniah tidak terdengar lagi.

Vygotsky mengatakan bahwa bahasa dan pikiran pada awalnya berkembang terpisah dan kemudian menyatu. Anak harus menggunakan bahasa untuk berkomunikasi dengan orang lain sebelum mereka dapat memfokuskan ke dalam pikiran-pikiran mereka sendiri. Anak juga harus berkomunikasi secara eksternal dan menggunakan bahasa untuk jangka waktu yang lama sebelum mereka membuat transisi dari kemampuan bicara eksternal menjadi internal. ${ }^{15}$

\section{Implikasi Dalam Pembelajaran Anak Usia Dini}

Pandangan Vygotsky terhadap pendidikan adalah pendidikan memegang peranan penting dalam membantu anak mempelajari alatalat budaya. Teori-teori pendidikan Vygotsky mempunyai dua implikasi utama teori pembelajarannya yaitu:

a. Menghendaki setting kelas kooperatif, sehingga siswa dapat saling berinteraksi dan saling memunculkan strategi-strategi pemecahan masalah yang efekif dalam masing-masing zone of proximal development mereka.

b. Pendekatan Vygotsky dalam pembelajaran dalam menekankan scaffolding. Jadi teori belajar vigotsky adalah salah satu teori belajar sosial sehingga sangat sesuai dengan model pembelajaran kooperatif

${ }^{15}$ http:// kompasiana.com/post/2011/01/01/teori-piaget-dan-vygotsky/ diakses 4 Maret 2017.

Jurnal Pelang̉i Jurnal pemikiran dan penelitian pendidikan Islam anak Usia Dini 
karena dalam model pembelajaran kooperatif terjadi interaktif social yaitu interaksi antara siswa dengan siswa dan antara siswa dengan guru dalam usaha menemukan konsep-konsep dan pemecahan masalah.

c. Walaupun Vygotsky dan Burner telah mengusulkan peranan yang lebih penting bagi orang dewasa dalam pembelajaran anak-anak dari pada peran yang diusulkan Peaget, keduanya tidak mendukung pengajaran diaktivis diganti sepenuhnya. Sebaliknya mereka malah menyatakan walaupun anak dilibatkan dalam pembelajaran aktif, guru harus aktif mendampingi setiap kegiatan anak-anak. Dalam istilah teoristis ini berarti anak-anak bekerja dalam zona perkembangan proksimal dan guru menyediakan scaffolding bagi anak.

d. Secara khusus Vygotsky mengemukakan bahwa disamping guru, teman sebaya juga berpengaruh pada perkembangan kognitif anak. Berlawanan dengan pembelajaran lewat penemuan individu (individual discovery learning) kerja kelompok secara kooperatif tampaknya mempercepat perkembangan anak.

e. Gagasan tentang kelompok kerja kreatif ini diperluas menjadi pengajaran pribadi oleh teman sebaya, yaitu seorang anak mengajari anak lainnya yang agak tertinggal di dalam pelajaran. Foot et al, menjelaskan pengajaran oleh teman sebaya ini dengan menggunakan teori Vygotsky. Satu anak bisa lebih efektif membimbing anak lainnya melewati ZPD karena mereka sendiri baru saja melewati tahap itu sehingga bisa dengan mudah melihat kesulitan-kesulitan yang dihadapi anak lain dan menyediakan scaffolding yang sesuai.

\section{KESIMPULAN}

Berdasarkan pembahasan di atas dapat ditarik sebuah kesimpulan yaitu, Vygotsky lebih menekankan pada konsep sosiokultural, yaitu konteks sosial dan interaksi dengan orang lain dalam proses belajar anak. Vygotsky juga yakin suatu pembelajaran tidak hanya terjadi saat di sekolah atau dari guru saja, tetapi suatu pembelajaran dapat terjadi saat anak-anak bekerja menangani tugas-tugas yang belum pernah dipelajari disekolah namun tugas-tugas itu bisa dikerjakannya dengan baik, misalnya di masyarakat. Dari Vygotsky, ada dua teori belajar yaitu tentang Zone of Proximal Development (ZPD) dan peranan konteks sosial 
dan kebudayaan dalam belajar.

Adapun Implikasinya dalam pembelajaran yaitu lebih menggunakan model pembelajaran kooperatif, sehingga anak dapat saling berinteraksi dan saling memunculkan strategi-strategi pemecahan masalah yang efekif dalam masng-masing zone of proximal development mereka. Sehingga kerja kelompok secara kooperatif ini juga tampaknya mempercepat perkembangan anak

\section{REFERENSI}

Abdul Rahman Sholeh, 2005, Pendidikan Agama dan Pengembangn Untuk Bangsa, Jakarta: PT. Raja Grafindo Persada.

John W Santrok, 2007, Psikologi Pendidikan, Jakarta: Kencana Media Group.

Mena \& Eyer, 2009, Infants, Toddlers, And Caregivers. New York: McGraw11.

Robert E Salvin, 2008, Psikologi Pendidikan Teori E Praktik, Jakarta: Indeks Person

Saputra Angga, Kompetensi Pedagogik Guru PAUD dalam Meningkatkan Nilai-Nilai Sosial, Moral dan Keagamaan Melalui Metode Bercerita, KINDERGARTEN; Journal of Islamic Early Childhood Education. Vol. 3, No. 1, April 2020. Hal. 85-91.

Wulandari Retnaningrum, Peningkatan Perkembangan Kognitif Anak Usia Melalui Media Bermain Memancing. Jurnal Pendidikan dan Pemberdayaan Masyarakat. Vol. 3 No. 2, November 2016. (207218).

Penney Upton, 2012, Psikologi Perkembangan, Jakarta: Erlangga.

L. S. Vygotsky, 1979, Mind In Society The Development Of Hinher Psychological, Amerika, Processes. 